\title{
Cardiac tumors: leiomyosarcoma - a case report
}

\author{
Włodzimierz Gierlak ${ }^{1}$, Joanna Syska-Sumińska ${ }^{1}$, Piotr Zieliński ${ }^{1}$, Mirosław Dłużniewski ${ }^{1}$, Jerzy Sadowski ${ }^{2}$ \\ ${ }^{1}$ Department of Cardiology, Hypertension, and Internal Diseases, Second Faculty of Medicine, \\ Medical University of Warsaw, Bródnowski Masovian Hospital, Warsaw, Poland \\ ${ }^{2}$ Department of Cardiovascular Surgery and Transplantation, Institute of Cardiology, Collegium Medicum \\ of the Jagiellonian University, Pope John Paul II Hospital in Krakow, Poland
}

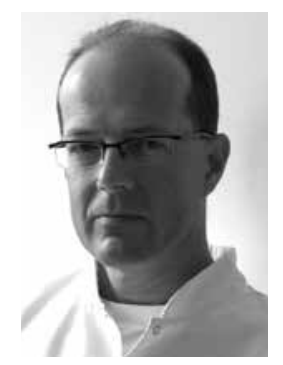

Kardiochirurgia i Torakochirurgia Polska 2015; 12 (3): 251-254

\begin{abstract}
We present a case report of a 60-year-old woman with a long history of leiomyosarcoma in different locations. She was admitted to the clinic due to a left ventricular tumor diagnosed in ECHO examination. The patient was qualified for radical tumor resection. The early postoperative period was complicated due to low cardiac output syndrome and bradyarrhythmia requiring temporary cardiac pacing. Optimized pharmacological therapy resulted in a gradual reduction of symptoms and a clinical improvement of congestive heart failure (NYHA III NYHA II). Due to the radical nature of the surgery, the patient was not referred for supplementary treatment. The follow-up currently exceeds 12 months - no new metastases have been found. This case provides an example of how to diagnose and treat heart tumors.
\end{abstract}

Key words: cardiac tumor, leiomyosarcoma, surgery.

\section{Streszczenie}

Pacjentka, 60 lat, od kilku lat leczona z powodu mięśniakomięsaka gładkokomórkowego (leiomyosarcoma), w różnych lokalizacjach, ze zdiagnozowanym guzem serca, została poddana leczeniu operacyjnemu wycięcia guza lewej komory serca. Wczesny okres pooperacyjny był powikłany wystąpieniem zespołu małego rzutu oraz bradyarytmią wymagającą zastosowania czasowej stymulacji zewnętrznej serca. W dalszym okresie leczenia szpitalnego ze względu na objawy niewydolności serca włączono odpowiednią farmakoterapię, uzyskując wyrównanie stanu chorej (NYHA III). Ze względu na radykalny charakter zabiegu nie podejmowano uzupełniających metod leczenia. Okres leczenia ambulatoryjnego był niepowikłany, stan chorej stabilny, obserwowano stopniową poprawę wydolności fizycznej (NYHA III - NYHA II). Obecnie okres obserwacji odległej przekroczył 12 miesięcy, nie stwierdzono nowych ognisk wzrostu nowotworu na podstawie badań ECHO i tomografii komputerowej (TK). Chora prowadzi normalny tryb życia. Na podstawie prezentowanego przypadku omówiono aktualnie stosowane postępowanie w przypadku guzów serca.

Słowa kluczowe: guz serca, leiomyosarcoma, kardiochirurgia.

airway pressure (CPAP) for obstructive sleep apnea. Her medical history included incidents of angioedema during attempts at antihypertensive treatment with angiotensinconverting enzyme (ACE) inhibitors. From 2004, the patient was treated for leiomyosarcoma located primarily in the uterus. The patient underwent numerous surgical procedures (extirpation of the uterus, removal of a tumor in the right lumbar area, removal of a tumor in the right thigh, removal of a tumor in the left arm). Surgical treatment was supplemented by radio- and chemotherapy. The patient was referred to the Cardiology Clinic after a cardiac tumor was revealed in follow-up echocardiography. The tumor with jagged edges $(35 \times 35 \mathrm{~mm})$ filled the apical portion of the left ventricle.

Address for correspondence: Włodzimierz Gierlak MD, PhD, Department of Cardiology, Hypertension and Internal Diseases, Second Faculty of Medicine, Medical University of Warsaw, Bródnowski Masovian Hospital, 8 Kondratowicza St., 03-242 Warsaw, Poland, phone: +48 22 3265605, e-mail: gierlak.w@wp.pl 


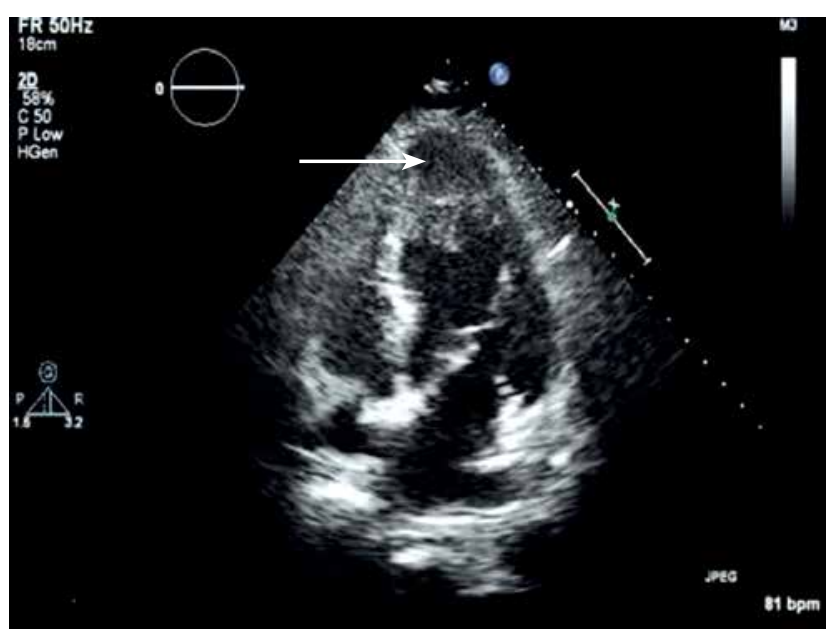

Fig. 1. Left ventricular tumor. Transthoracic echocardiographic examination, apical four-chamber view. The tumor is marked with an arrow

Cardiac diagnostics was conducted due to the gradually deteriorating exercise tolerance, even though the patient's fatigability could have been attributed to her age, body type, inactive lifestyle, and long-term hypertension with left ventricular hypertrophy leading to diastolic heart failure. Regular cardiac function in physical examination (76/min), quiet systolic murmur in the apex and Erb's point, no auscultatory changes over the lung fields, trace of peripheral swelling, and normal blood pressure with the currently applied treatment were noted. After a cardiological consultation, the patient was qualified for surgical treatment of the tumor in the left ventricle. Due to the fact that the echocardiographic image clearly corresponded to a metastatic course of leiomyosarcoma, other methods of diagnostic imaging were not utilized (Fig. 1). The patient was operated on with cardiopulmonary bypass, under systemic hypothermia $\left(28^{\circ} \mathrm{C}\right)$, using crystalloid cardioplegia. The left ventricle was opened on the anterior wall between the posterior interventricular artery and the diagonal branch.

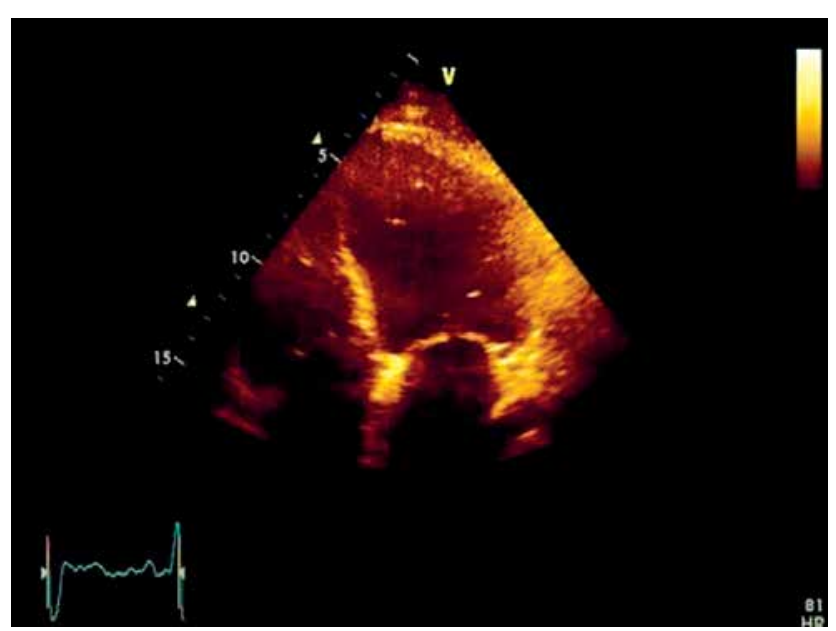

Fig. 2. Echocardiographic image taken on the $15^{\text {th }}$ day after tumor resection, apical four-chamber view
A large tumor $(3 \times 3 \mathrm{~cm})$ was removed from the wall of the left ventricle with the coagulation of the cut edges. The left ventricle was closed using felt-supported sutures. Aortic cross-clamping time during the procedure was 19 minutes, while cardiopulmonary bypass time was 45 minutes. The early postoperative period at the intensive care unit was extended due to low cardiac output syndrome (EF 26\%), requiring the inclusion of catecholamines, and bradyarrhythmia, necessitating - temporary external cardiac pacing. The patient was moved to the Cardiology Clinic on the $15^{\text {th }}$ postoperative day (Fig. 2 and 3). Physical examination revealed the following: wound healed by first intention, tachycardia $-100 / \mathrm{min}$, blood pressure $-135 / 85 \mathrm{mmHg}$, crackles at the base of both lungs, traces of lower leg swelling, lack of postcardiotomy syndrome in echocardiography. Signs of heart failure requiring the implementation of an appropriate treatment were dominant during subsequent hospitalization. Due to the presence of angioedema in the patient's medical history, ACE-I (angiotensin-converting-enzyme inhibitor) treatment was not applied. A follow-up ECHO examination revealed a slight improvement in left ventricular ejection fraction (LVEF 30\%).

The applied pharmacological treatment stabilized the patient (NYHA III); a six-minute walk test with exercise tolerance at the level of $280 \mathrm{~m}$ was conducted before discharge. Due to the radical nature of the tumor resection, no supplementary methods of treatment were implemented. The period of outpatient treatment, including cardiac rehabilitation, was uneventful; the condition of the patient was stable, with a gradual improvement of physical performance (NYHA III - NYHA II). After 3 months, a follow-up echocardiographic examination showed a further improvement of left ventricular ejection fraction (LVEF 38\%). Currently, the long-term follow-up exceeds 12 months; no new neoplastic foci were found in ECHO and computed tomography; left ventricular ejection fraction remains stable (LVEF 40\%). The good clinical condition of the patient enables her to conduct her daily activities at a level sufficient for her needs.

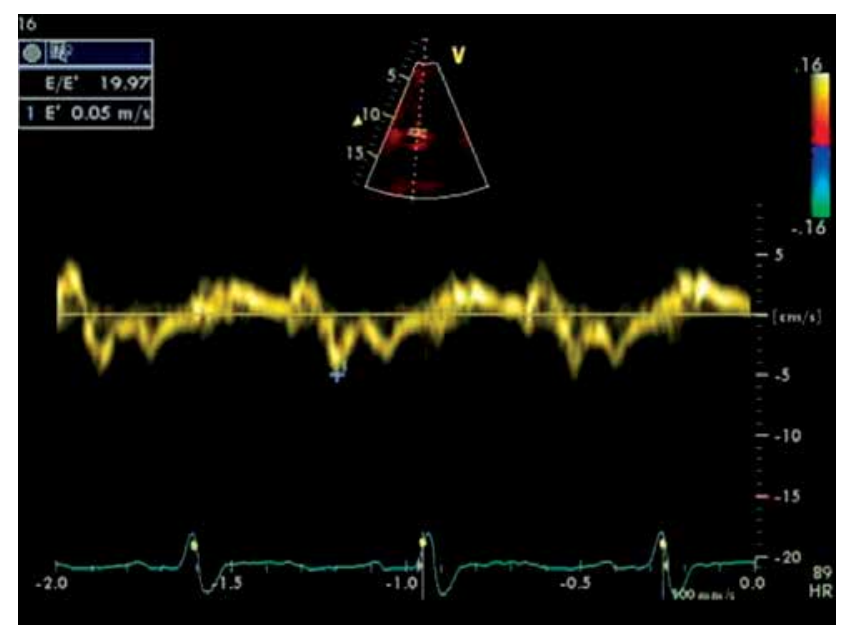

Fig. 3. Echocardiographic image taken on the $15^{\text {th }}$ day after tumor resection, tissue Doppler imaging. High E/E' ratio indicates increased left ventricular filling pressure 


\section{Discussion}

Primary cardiac tumors are rare; metastatic tumors are encountered more frequently. These tumors are benign in $75 \%$ of cases and malignant in $25 \%$. The most common benign cardiac tumors include myxoma (approximately half of all cases), papillary fibroelastoma, and lipoma (16\% for each type). Sarcomas constitute the dominant group of malignant tumors (95\%), the most common being angiosarcoma (28\%). It is important to emphasize that metastatic heart tumors are over 20 times more frequent than primary tumors and are found in 10-12\% of patients with neoplastic diseases [12]. Heart metastasis occurs most frequently in the course of lung, breast, and kidney cancers as well as in the case of lymphomas and melanoma. The prevalence of leiomyosarcoma in the adult population is estimated at $5 \%$ of all cardiac tumors and $1 \%$ of all neoplasms. Sarcomas develop from mesenchymal tissue, which explains their diversity. More than half of the patients are men aged between 50 and 60 years. Leiomyosarcoma, as opposed to angiosarcomas, is characterized by slow, asymptomatic growth. Leiomyosarcoma is most commonly localized in the retroperitoneal space (19\%), but it may also develop in the uterus, stomach, intestines, skin, and vascular walls. Leiomyosarcoma of the heart is usually located in the left atrium, but it may also occur in the left ventricle, as in the case presented above. The tumors are usually situated on a wide, gelatinous base. It is assumed that some of them may develop from the smooth muscles of pulmonary veins. Due to their oligosymptomatic course, cardiac tumors are underdiagnosed; diagnosis is established intraoperatively or during an autopsy. The development of medical imaging methods enabled earlier diagnosis of cardiac tumors. Due to the slow and asymptomatic growth and lack of specific biochemical markers, the main role in diagnostics is played by imaging methods, mainly ultrasound [1]. In the case of cardiac tumors, transthoracic echocardiography is of primary importance for establishing a preliminary diagnosis. An echocardiographic diagnosis of a cardiac tumor requires differentiation; apart from tumors, it is necessary to consider thrombi or bacterial vegetation. The final diagnosis is frequently reached through correct differentiation based on the patient's disease history as well as tumor location and structure [13]. Other methods of medical imaging used in the diagnostics of cardiac tumors include transesophageal echocardiography and computed tomography. Magnetic resonance remains the reference imaging examination in the course of the diagnostic process [14]. The results of imaging examinations enable the assessment of the anatomical condition in the area of the tumor, which allows for the establishment of the extent of myocardial, pericardial, and extracardiac involvement [15].

Possible clinical symptoms: tumors in cardiac cavities usually cause heart failure with its typical symptomatology, while cardiac dysrhythmia may be expected in the case of intramural tumors. The clinical manifestation of cardiac tumors is dependent on the influence of tumor location and size on the hemodynamics of the heart. Moreover, left heart tumors may cause embolisms in the systemic circulation, in the form of ischemic stroke, infarctions of abdominal organs, and peripheral embolisms in extremities. In advanced forms of the disease, tumor growth is frequently accompanied by the presence of bloody exudate in the pericardial sac, which may result in the development of life-threatening tamponade. The treatment of choice for cardiac tumors is tumor resection. The general operative indications for cardiac tumors result from the hemodynamic disorders associated with tumor growth, increased risk of embolism, and cardiac dysrhythmia. The main factors determining the results of cardiac surgical treatment include the general condition of the patient, the stage of the underlying neoplastic process (infiltration by continuity), and the occurrence of clinically significant distant metastases (crucial for prognosis). Therefore, surgical treatment is rarely applied, and long-term surgical treatment results are poor. In the case of the present patient, the ailments were associated with heart failure in NYHA class II; however, as a result of the irregular, jagged surface of the tumor revealed in echocardiography, this form of the disease was characterized by increased risk of embolic complications. The condition of the patient, anatomy of the tumor, and lack of metastases to other organs at the current stage of the disease enabled the qualification of the patient for surgical treatment. In the case of malignant tumors, a surgical procedure is not a fully effective method of treatment [16], but isolated cases of lasting recovery after radical tumor resection have been described in the literature [17]. The factors determining unfavorable prognosis include incomplete tumor resection and high grade of tumor differentiation (G3) leading to the rapid spread of metastases, mainly to the lungs and the brain [18]. The effectiveness of adjuvant radio- and chemotherapy in the treatment of leiomyosarcoma has not yet been explicitly established, while the applied therapeutic schemes were transferred from the treatment of soft tissue sarcomas.

In the present case, the occurrence of low cardiac output syndrome, treated with a catecholamine infusion, and symptomatic bradyarrhythmia, requiring temporary external cardiac pacing, constituted significant problems in the early postoperative period. The complications were associated with the extent of the procedure, the necessary coagulation of the tumor resection line with subsequent necrosis of the adjacent tissue, and postoperative myocardial stunning. The applied pharmacological treatment and cardiac rehabilitation enabled the reduction of heart failure symptoms to NYHA class II, with a gradual improvement of left ventricular ejection fraction. A standard management after cardiac tumor resection is yet to be established; the prognosis is not certain due to the risk of local recurrence, occurring in half of the patients undergoing surgery, as well as the appearance of metastases, observed in $20-40 \%$ of cases [19]. In cases of primary cardiac tumors and incomplete tumor resection, the average time of survival is estimated at 6 to 12 months, while, in the case of radical tumor resection, various reports estimate it at 24-45 months; 
radical procedures may consist in autotransplantation with the reconstruction of the removed elements of the heart [20]. The majority of reports concerning cardiac surgery and adjuvant chemotherapy, however, estimate the average survival time at approximately 18 months. Sarcomas are characterized by the recurrence of hyperplasia, which necessitates regular clinical monitoring with diagnostic imaging methods (watchful waiting strategy). In the case of leiomyosarcoma, it is recommended to carefully consider the possibility of local recurrence and metastasis to the brain and lungs. Currently, the long-term follow-up of the present patient exceeds 12 months. No new neoplastic foci have been revealed by ECHO and $\mathrm{CT}$ examinations. The good clinical condition of the patient enables daily activity at a level sufficient for her needs.

\section{Disclosure}

Authors report no conflict of interest.

\section{References}

1. Snarska J, Razak HH, Kamiński F, Szajda SD, Werel D, Zimnoch L, Siemiątkowski A. Olbrzymi guz przestrzeni zaotrzewnowej o charakterze leiomyosarcoma: opis przypadku. Współcz Onkol 2007; 11: 92-95.

2. Yajima K, Shirai Y, Fujita N, Sato D, Umezu H, Hatakeyama K. A giant subcutaneous leiomyosarcoma arising arising in the inquinal region. World J Surg Oncol 2005; 3: 14

3. Kaddu S, Beham A, Cerroni L, Humer-Fuchs U, Salmhofer W, Kerl H, Soyer HP. Cutaneous leiomyosarcoma. Am J Surg Pathol 1997; 21: 979-987.

4. Rydzek J, Gąsior Z. Guz przerzutowy leiomyosarcoma w prawej komorze. Kardiol Pol 2010; 68: 1370-1373.

5. Collins NJ, Barlow MA, Woodford PA, Hayes PC. Intracardiac extension of metastatic pulmonary leiomyosarcoma. Heart Lung Circ 2005; 14: 121-122.
6. Antón FM, Herraez AC, Vázquez JP, Gómez Díaz R, Aragoncillo P, Díaz-Rubio García E. Cardiac metastasis from uterine leiomyosarcoma. Clin Transl Oncol 2006; 8: 375-378.

7. Parissis H, Akbar MT, Young V. Primary leiomyosarcoma of the right atrium: case report and literature update. J Cardiothorac Surg 2010; 5: 80.

8. Jaster M, Gutberlet M, Dinkloh N, Schneider P, Schultheiss HP, Morguet AJ. Ventricular tachycardia indicating cardiac involvement in metastatic leiomyosarcoma. J Clin Oncol 2006; 24: 3502-3504.

9. Tschan ChA, Mirzayan MJ, Stan AC, Pichlmaier MA, Krauss JK. Concomitant cardiac and cerebral leiomyosarcoma: a challenge for surgical and adjuvant therapy. J Thorac Cardiovasc Surg 2009; 137: e12-e14.

10. Nguyen SKA, Wong F. Right atrial metastasis of uterine leiomyosarcoma causing obstructive shock. Curr Oncol 2012; 19: e292-e294.

11. Dencker M, Valind S, Stagmo M. Right ventricular metastasis of leiomyosarcoma. Cardiovasc Ultrasound 2009; 7: 20.

12. Neragi-Miandoab S, Kim J, Vlahakes GJ. Malignant tumours of the heart: a review of tumor type, diagnosis and therapy. Clin Oncol (R Coll Radiol) 2007; 19: 748-756.

13. Peters PJ, Reinhardt S. The echocardiographic evaluation of intracardiac masses: a review. J Am Soc Echocardiogr 2006; 19: 230-240.

14. Restrepo CS, Largoza A, Lemos DF, Diethelm L, Koshy P, Castillo P, Gomez R, Moncada R, Pandit M. CT and MR imaging findings of malignant cardiac tumors. Curr Probl Diagn Radiol 2005; 34: 12-21.

15. Auger D, Pressacco J, Marcotte F, Tremblay A, Dore A, Ducharme A. Cardiac masses: an integrative approach using echocardiography and other imaging modalities. Heart 2011; 97: 1101-1109.

16. Tai P, Yu E. Cardiac tumours. J Oncol 2009; 1: 1-8.

17. Catton $C$. The management of malignant cardiac tumours: clinical considerations. Semin Diagn Pathol 2008; 25: 69-75.

18. Jarek D, Stanisławski R, Mak M, Klausa F, Skiba J. Leiomyosarcoma w tętnicy płucnej: trudny problem terapeutyczny, niepewne rokowanie. Kardioch Torakoch Pol 2005; 2: 78-81.

19. McKee MD, Liu DF, Brooks JJ, Gibbs JF, Driscoll DL, Kraybill WG. The prognostic significance of margin width for extremity and trunk sarcoma. J Surg Oncol 2004; 85: 68-76.

20. Hoffmeier A, Deiters S, Schmidt C, Tjan TD, Schmid C, Drees G, Fallenberg EM, Scheld HH. Radical resection of cardiac sarcoma. Thorac Cardiovasc Surg 2004; 52: 77-81. 